\title{
REVIEW
}

\section{Epigenetic changes in fibroblasts drive cancer metabolism and differentiation}

\author{
Rajeev Mishra', Subhash Haldar², Surabhi Suchanti1 and Neil A Bhowmick ${ }^{3,4}$ \\ 'Department of Biosciences, Manipal University Jaipur, Jaipur, Rajasthan, India \\ 2Department of Biotechnology, Brainware University, Kolkata, India \\ ${ }^{3}$ Department of Medicine, Cedars-Sinai Medical Center, Los Angeles, California, USA \\ ${ }^{4}$ Department of Research, Greater Los Angeles Veterans Administration, Los Angeles, California, USA
}

Correspondence should be addressed to N A Bhowmick: bhowmickn@cshs.org

\begin{abstract}
Genomic changes that drive cancer initiation and progression contribute to the co-evolution of the adjacent stroma. The nature of the stromal reprogramming involves differential DNA methylation patterns and levels that change in response to the tumor and systemic therapeutic intervention. Epigenetic reprogramming in carcinomaassociated fibroblasts are robust biomarkers for cancer progression and have a transcriptional impact that support cancer epithelial progression in a paracrine manner. For prostate cancer, promoter hypermethylation and silencing of the RasGAP, RASAL3 that resulted in the activation of Ras signaling in carcinoma-associated fibroblasts. Stromal Ras activity initiated a process of macropinocytosis that provided prostate cancer epithelia with abundant glutamine for metabolic conversion to fuel its proliferation and a signal to transdifferentiate into a neuroendocrine phenotype. This epigenetic oncogenic metabolic/signaling axis seemed to be further potentiated by androgen receptor signaling antagonists and contributed to therapeutic resistance. Intervention of stromal signaling may complement conventional therapies targeting the cancer cell.
\end{abstract}

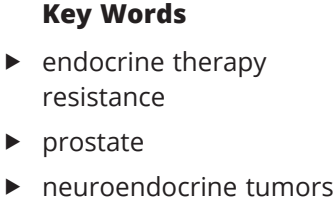

Endocrine-Related Cancer (2019) 26, R673-R688

\section{Chromatin modification in cancer: a brief overview}

Cancer is a general term for a group of diseases that diverge with respect to its origin and is characterized by uncontrolled proliferation with the potential for metastatic progression (Hanahan \& Weinberg 2000, Chaffer \& Weinberg 2011, Hanahan \& Weinberg 2011). Cell proliferation is normally tightly regulated at the gene level with dynamic chromatin modifications (Perino \& Veenstra 2016). Chromatin structure is central for the regulation of gene expression either by organizing the structure of promoters and regulatory elements or by providing accessibility to transcription factor binding at regulatory elements (Tirosh \& Barkai 2008). One of the prime epigenetic phenomena in cancer is suppression or downregulation of tumor suppressor genes through aberrant promoter methylation and deacetylation, often associated with condensing the chromatin structure and preventing transcription factor loading, resulting in gene silencing (Robertson 2001, Luczak \& Jagodzinski 2006). Conversely, the acetylation and demethylation of the gene-body can also result in gene silencing. The epigenetic activation of oncogenes on the other hand seem to be less associated with direct DNA or histone methylation/ acetylation of the oncogenes themselves, but rather miRNAs that can indirectly regulate tumorigenic potential (c) 2019 The authors Published by Bioscientifica Ltd. Printed in Great Britain

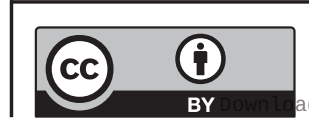

This work is licensed under a Creative Commons Attribution 4.0 International License. 
(Zhang et al. 2007, Mi et al. 2010, Yan et al. 2015). The role of miRNAs in the microenvironment is not discussed in this review as they are well reviewed elsewhere (Rupaimoole et al. 2016, Smith et al. 2017). However, the regulation of oncogene activity regulatory proteins of, as opposed to direct oncogene/tumor suppressor expression, can also result from DNA/histone modification. The tight oncogenic regulation suggests multiple mechanisms by which they can be subverted in the events leading to cancer.

The addition of a methyl group $\left(\mathrm{CH}_{3}\right)$ at fifth carbon position of the cytosine ring of DNA, termed, 5 -methylcytosine $(5 \mathrm{mC})$, predominantly occurs in CpGrich sequences. Somatic, non-stem cells, normally have hypomethylated $\mathrm{CpG}$ islands in promoter sequences (Moore et al. 2013). However, aberrant promoter hypermethylation of multiple tumor-suppressor genes is associated with the upregulation of DNA methyltransferases (DNMTs) in multiple cancer types (Jin \& Robertson 2013, Moore et al. 2013). The DNMT family comprises four members which include DNMT1, DNMT3A, DNMT3B and DNMT3L. All members of the family possess inherent enzyme activity except DNMT3L (Jin \& Robertson 2013). While DNMT1 functions during DNA replication to maintain the DNA methylation pattern from the parental DNA strand onto the newly synthesized daughter strand, DNMT3a and DNMT3b are responsible for establishing de novo methylation pattern to unmodified DNA (Okano et al. 1998, 1999, Riggs \& Xiong 2004, Egger et al. 2006, Goll et al. 2006). Epigenetic cancer therapeutic targets DNA/histone methylation in order to reverse chromatin remodeling (Sproul \& Meehan 2013). An feature of cancer cell is the reduced total global DNA methylation in the context of enriched DNA methylation at certain promoter CpG islands (Wu et al. 2018). Laird et al. showed that heterozygotic mice with null mutation of Dnmt1, when treated with specific inhibitors of DNA methylation, such as 5-aza- 2 -deoxycytidine (5-aza-dC) significantly reduced tumor formation in Apc $\mathrm{Min}^{+/-}$ mice (Takebayashi et al. 2007). Additional studies with gene knockout analysis in mice have shown that, a Dnmt1 hypomorphic allele (causing partial loss of function) can suppress polyp formation and CpG island methylation (Eads et al. 2002). In particular, studies have demonstrated that DNMT1 overexpression correlates with colon tumors, compared to non-malignant adjacent stroma (Honeywell et al. 2018). DNA methylation marks also involve active demethylation of $5 \mathrm{mC}$ by oxidizing enzymes including the ten-eleven translocation (TET) enzymes (TET1, TET2, TET3) as well as associated histone proteins by demethylase KDM4A/JHDM2A. Interestingly, epigenetic regulation can itself be regulated by metabolic intermediates. For example, the TCA cycle metabolite $\alpha$-ketoglutarate is an inducer of TET2 (Raffel et al. 2017). The subsequent downstream metabolites, succinate and fumarate, promoted histone demethylation by KDM4A/JHDM2A (Xiao et al. 2012). New findings on the relationship between chromatin modification and cancer metabolism provide new opportunities for epigenetic therapy.

\section{Epigenetic coevolution of stromal fibroblastic cells in response to tumorigenesis}

It is now established that carcinogenesis involves reciprocal interactions between cancer cells and components of the surrounding microenvironment consisting of extracellular matrix, fibroblasts, vasculatureassociated endothelia and pericytes, as well as immune cells and occasionally adipose cells (Plava et al. 2019). Based on the pro-tumorigenic role these non-tumorigenic components have, tumor microenvironment-targeted interventions have attracted notable attention in cancer therapy (Dey 2011, Quail \& Joyce 2017). Prominently, angiogenesis inhibitors have been practice-changing for a few cancer types, but interestingly had a lesser impact on cancer care than originally anticipated. Regulators of fibrosis have had limited efficacy. While immune therapy targeting $\mathrm{T}$ cell activation has taken cancer care by storm recently, thus far under $20 \%$ of melanoma and lung cancer patients demonstrate lasting benefit. Interestingly, there is a distinct change in the chromatin-accessible regions of exhausted $\mathrm{T}$ cells that is not alterable by immune checkpoint inhibition (Pauken et al. 2016, Sen et al. 2016). The understanding of the most abundant cell type of the solid tumor microenvironment, the fibroblasts, remains largely unknown. Not without controversy, cancerassociated fibroblasts (CAF), is considered not to be driven by genomic mutations (Hill et al. 2005, Li et al. 2007, Qiu et al. 2008, Bianchi-Frias et al. 2016). However, the seminal finding by Cunha and colleagues that CAFs have the capacity to maintain its tumor-inductive capacity in the absence of the constant signals from cancer cells for a period of time, suggested an inherent 'memory' (Olumi et al. 1999, Hayward et al. 2001). As evidence, CAF can be isolated from patient tissues, cultured, and then transferred to mice with non-tumorigenic cells to develop a tumor. In the absence of mutations, the protumorigenic phenotype of CAF is found to be driven by

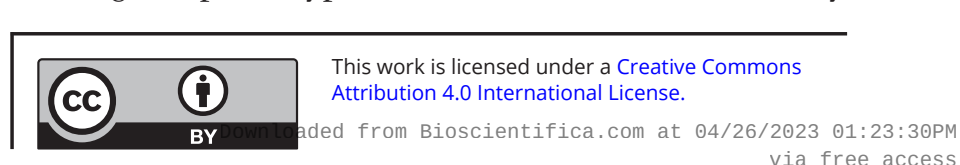


epigenetic mechanisms associated with promoter DNA methylation (Dumont et al. 2008, Gascard \& Tlsty 2016).

CAFs are the dominant cell type in tumor microenvironment, with both pro- and anti-tumorigenic capacity (Placencio et al. 2008, Kalluri 2016, LeBleu \& Kalluri 2018). The net effect of paracrine signaling crosstalk between CAFs and the cancer epithelia provides avenues for disrupting pro-tumorigenic signaling (Wu et al. 2012). In contrast to normal tissue-associated fibroblasts (NAFs), the epigenetic programming in CAFs represents a durable change that is able to promote tumor growth (Fiori et al. 2019). The distinct contribution of TME epigenetic landscapes in tumorigenesis was first highlighted by $\mathrm{Hu}$ and colleagues ( $\mathrm{Hu}$ et al. 2005) by developing a novel method - methylation-specific digital karyotyping tissue obtained from epithelial and stromal fibroblasts from normal breast and in situ and invasive breast carcinomas. This study highlighted that epigenetic landscape has a role in the maintenance of the abnormal microenvironment in breast cancer. In prostate cancer, pi-class glutathione S-transferase gene (GSTP1) promoter is methylated in $>90 \%$ cases (Lee et al. 1994). This seminal study demonstrated distinct GSTP1 gene promoter methylation of the stromal cells in prostate cancer. Although the primary role of GSTP1 is in the detoxification of carcinogens (Allocati et al. 2018), it is not involved in the suppression of cancer cell growth and cannot be classified as a tumor suppressor gene (TSG); however, its aberrant silencing in CAFs may create a permissive microenvironment for tumorigenesis (Lee 2007). In agreement RodriguezCanales et al. demonstrated significant topographical differences and distinct area of stromal methylation of the stroma especially at the center of the tumor in the prostate using laser capture microdissection (RodriguezCanales et al. 2007). We have reported that the epigenetic silencing of the TGF- $\beta$ type II receptor (Tgfbr2) in prostatic CAF can be causative for GSTP1 promoter methylation, as the knockout of the Tgfbr2 resulted in GSTP1 silencing in addition to a number of DNA damage repair genes (Banerjee et al. 2014). In addition, prostatic human CAF and mouse transgenic knockout of Tgfbr 2 demonstrated elevated DNA methyltransferases I (DNMT1) activity and histone $\mathrm{H} 3$ lysine 9 trimethylation (H3K9me3) associated with greater promoter methylation. Notably, restoring the expression of the epigenetically silenced genes in the CAF using 5-azacitidine led to reduced tumor progression (Banerjee et al. 2014). Promoter DNA and histone methylation can mediate a tumor permissive environment (El-Osta \& Wolffe 2000, Rose \& Klose 2014). A recent study showed that CAFs with a large number of
H3K27me3 changes had greater tumor-promoting effects, associated with the secretion of the paracrine factor WNT5a (Maeda et al. 2019). The epigenetic landscape of PCa CAF has diagnostic and grading capacity of PCa (Gordetsky \& Epstein 2016, Pidsley et al. 2018).

\section{DNA methylation and histone modification studies in CAF}

Recent advancement in 'omics' technologies have allowed for genome-wide profiling of genome-scale DNA methylation both at a single-nucleotide and at a single-cell resolution (Lo \& Zhou 2018). These methylation techniques are primarily based on the concept that treatment of sodium bisulfite on DNA leads to the conversion of nonmethylated cytosines to uracil whilst maintaining 5-methylcytosine $(5 \mathrm{mC})$ unchanged (commonly called as protected region) (Clark et al. 1994). Bisulphite conversion is still considered to be the 'gold standard' to detect DNA methylation patterns. In addition, alternative methylcytosine-specific enrichment technologies, such as methylated DNA immunoprecipitation (MeDIP) and methyl-CpG-binding technologies are region-based approaches in whole genomes, therefore, do not deliver the detail of DNA methylation patterns (Bock et al. 2010). Incorporation of next-generation sequencing methods with bisulfite conversion is the basis for reduced representation (RRBS) or whole genome (WGBS) data to identify genome-wide CpG coverage (Harris et al. 2010). We performed first application of RRBS technology in analyzing DNA methylation pattern in fibroblasts (Mishra et al. 2018). Comparing the DNA methylome analysis of prostatic NAF and CAF, we recognized genes that had reported roles in tumor progression, suppression, and metastasis (Table 1). There were 18 tumor-promoting, 11 suppressing, 2 metastasis regulatory gene promoters' hypermethylated in the prostatic CAFs. Heat maps of the genes suggest critical novel biomarkers for prostate cancer (Fig. 1). The rational for focusing on known tumor regulators in the non-transformed fibroblastic cells is based on significant evidence that such genes in fibroblasts have distinct paracrine effects on associated epithelia. Indeed, the forced expression of two oncogenic events are required to transform embryonic fibroblasts (Land et al. 1983). However, the effects on adjacent epithelia only seem to require a single such hit. For example, the loss of tumor suppressors, such as TGFBR2 or phosphatase and tensin homolog (PTEN) in prostate and breast fibroblasts, respectively, has been associated

This work is licensed under a Creative Commons Attribution 4.0 International License. ed from Bioscientifica.com at 04/26/2023 01:23:30PM 
Table 1 Differential promoter methylation of genes in prostatic CAF and NAF cells with roles as oncogene, tumor suppressor, and metastasis.

\begin{tabular}{lll}
\hline Name & Description \\
$\begin{array}{c}\text { Oncogene } \\
\text { MEDAG }\end{array}$ & Mesenteric estrogen-dependent adipogenesis
\end{tabular}

ALX1 Aristaless-like homeobox1

CACNA1C Calcium voltage-gated channel subunit alpha1 C

GPT2 Glutamic pyruvate transaminase GPT2

HSPA2 Heat shock-related 70-kDa protein 2

PVRL4 Poliovirus-receptor-like 4

LAMA3 Laminin alpha 3

NOS2 Nitric oxide synthase

FOXD2-AS1 FOXD2 adjacent opposite strand RNA1

SFRP4 Secreted frizzled-related protein 4 (SFRP4)

SH3RF2 SH3-domain-containing RING finger protein

CD74 Cluster of Differentiation 93

COBL cordon-bleu $\mathrm{WH} 2$ repeat protein)

NAV1 Neuron navigator 1

B3GNT1 $\quad \beta-1,3-N$-acetylglucosaminyltransferase 1

CD93 Cluster of Differentiation 93
Biological effect

Observed in almost all cases of papillary thyroid carcinomas. High expression was correlated with metastasis and poor disease-free survival.

Induces EMT and cell invasion in ovarian cancer cells by promoting Snail expression.

Expression was directly regulated by miR-363 whose high expression is associated with worse prognosis in diffuse large B-cell lymphoma (DLBCL).

Promotes tumorigenesis and stemness of breast cancer cells by activating the Shh signaling

Overexpression is correlated with tumor angiogenesis and poor prognosis in pancreatic carcinoma.

Associated with breast cancer transformation and involved in cell-to-cell attachment with monoclonal antibodies

The analysis identified a splice variant known to be involved in tumor cell invasion and progression.

Its expression was associated with brain metastases in mouse models of orthotopic breast cancer xenografts.

Promoted the progression of colorectal cancer by regulating EMT and Notch signaling pathway.

Elevated gene expression is associated with high grade disease and recurrent prostate cancer after surgery.

Regulates p21-activated kinase 4 (PAK4) protein stability. Ectopic expression limit apoptosis and enhances cell migration, colony formation and tumor growth.

In several forms of cancer, CD74 is up-regulated and associated with enhanced proliferation and metastatic potential

It is involved in the cancer cell morphogenesis, implicated in the acquisition of the neuron-like cell shape observed in neuroendocrine prostate cancer.

Expressed in brain astrocytoma, its expression was positively correlated with the degree of malignancy

Wild-type but not mutant B3GNT1 in human prostate cancer cells led to increased levels of $\alpha$-dystroglycan glycosylation, associated with extracellular matrix.

A key regulator of glioma angiogenesis, acting via cytoskeletal rearrangements required for cell-cell and cell-matrix adhesion.
Reference

(Song et al. 2019)

(Yuan et al. 2013)

(Zhang et al. 2019)

(Cao et al. 2017)

(Zhai et al. 2017)

(Pavlova et al.

(Moller-Levet et al. 2009)

(Heinecke et al. 2014)

(Yang et al. 2017)

(Sandsmark et al. 2017)

(Kim et al. 2014)

(Schroder 2016)

(Lopes et al. 2016, Takayama et al. 2018)

(Xing et al. 2014)

(Buysse et al. 2013)

(Langenkamp et al. 2015)

(Continued) https://erc.bioscientifica.com https://doi.org/10.1530/ERC-19-0347
(C) 2019 The authors Published by Bioscientifica Ltd. Printed in Great Britain
This work is licensed under a Creative Commons Attribution 4.0 International License. 
Table 1 Continued.

\begin{tabular}{|c|c|}
\hline Name & Description \\
\hline NTRK1 & Neurotrophic receptor tyrosine \\
\hline SIX2 & SIX homeobox 2 \\
\hline \multicolumn{2}{|c|}{ Tumor suppressor } \\
\hline FES & c-fes protein-tyrosine kinase \\
\hline LSP1 & Lymphocyte-specific protein 1 \\
\hline
\end{tabular}

LIMCH1 Lim and calponin-homology domains 1

CDYL Chromodomain on y-like

CCDC68 Coiled-coil domain containing 68

ISYNA1 Inositol 3-phosphate synthase (ISYNA1)

LZTS3 Leucine zipper tumor suppressor family member 3

ING3 Inhibitor of growth

TBX4 T-box transcription factor Tbx4

RPL23A Ribosomal protein L23A gene

HOXA5 Homeobox A5

Metastasis

ESRP1 Epithelial splicing regulatory protein 1

ANXA2 Annexin A2

https://erc.bioscientifica.com https://doi.org/10.1530/ERC-19-0347
(C) 2019 The authors Published by Bioscientifica Ltd. Printed in Great Britain
Biological effect

Tumor samples from 3 of 91 patients with lung cancer (3.3\%) without known oncogenic alterations assayed by nextgeneration sequencing or fluorescence in situ hybridization demonstrated evidence of NTRK1 gene fusions

Transcription factor involved in organ development and breast cancer stem cells through the positive regulation of SOX2

Expression downregulated in colon tumors. Restoration of expression suppressed their colon cancer growth in soft agar.

Inhibits the growth of hepatocellular carcinoma by suppressing ERK $1 / 2$ phosphorylation. Patients with high LSP1 expression had significantly better overall survival.

Potentiates actin stress fiber assembly and stabilizes focal adhesions to negatively regulate cell spreading and migration

CDYL bridges REST and histone methyltransferases for gene repression and suppression of cellular transformation. Loss of heterozygosity associated with cervical cancer transformation.

Allows for centriol anchoring to microtubules in interphase cells. Directly associated with pancreatic cancer proliferation.

Ectopic ISYNA1 expression increased myo-inositol levels in the cells and suppressed tumor cell growth.

In silico characterization of LZTS3
its potential tumor suppressor.

Can activate $\mathrm{p} 53$ trans-activated promoters, including promoters of p21/waf1 and Bax. Overexpression can inhibit cell growth and induce apoptosis in head and neck cancers

Reduced expression suggests a worse prognosis for pancreatic cancer patients.

A component of the 605 ribosomal subunit exhibits anti-cancer function on the Hep-2 cells.

Loss of expression occurs frequently in breast cancer and correlates with higher pathological grade and poorer disease outcome.

Drives a switch from mesenchymal to epithelial phenotype characterized by reduced cell migration of ovarian cancer High-affinity binding for $\mathrm{Ca}$ and phospholipids like other annexin family members. Implicated in multiple cancer types to greater metastasis and poor prognosis.
Reference

(Vaishnavi et al. 2013)

(Wang et al. 2014 Oliphant et al. 2019)

(Delfino et al. 2006)

(Zhang et al. 2016)

(Lin et al. 2017)

(Mulligan et al. 2008)

(Radulovich et al. 2015)

(Koguchi et al. 2016)

(Teufel et al. 2005)

(Gou et al. 2014)

(Zong et al. 2011)

(Sun et al. 2012)

(Teo et al. 2016)

(Jeong et al. 2017)

(Christensen et al. 2018, Li et al. 2019) 

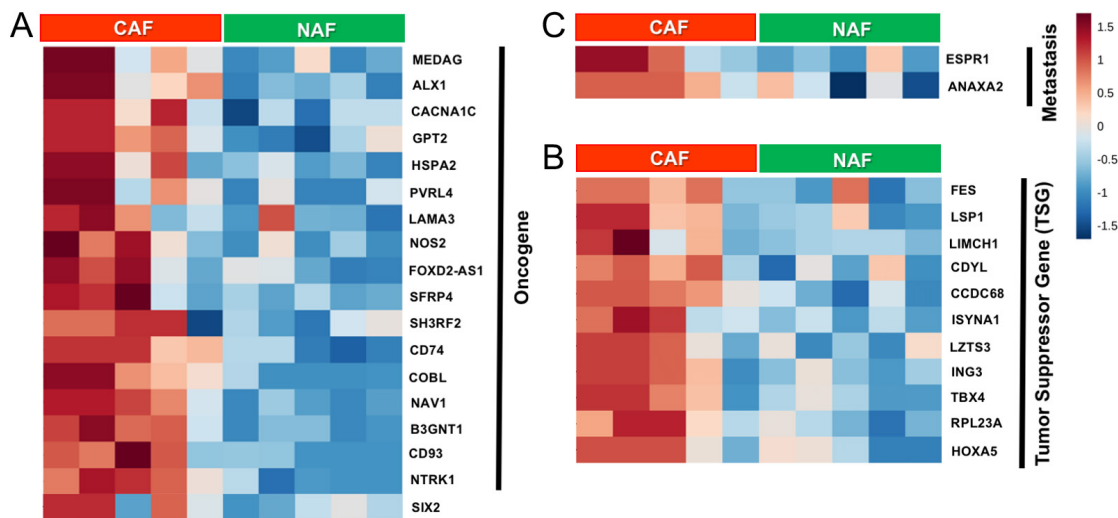

Figure 1

Heatmap summarizing DNA methylation levels of CpG repeats (blue color indicates hypomethylation and brown represents hypermethylation). (A) Hierarchical clustering and heatmap were generated for logarithmically transformed RRBS data and a columnwise normalization using MetaboAnalyst 3.0. (B) Tumor suppressor and (C) oncogenes identified from top 200 methylated genes differentially expressed between NAF and CAF are indicated. Each column represents a fibroblast sample, and each row represents the methylation level of indicated gene $(n=5)$ with breast and prostate cancer mouse models (Bhowmick et al. 2004, Cheng et al. 2005, Trimboli et al. 2009). In parallel, oncogene expression of cyclin D1 (CCND1) and $C M Y C$ in the $\mathrm{CAF}$ has been reported to promote tumorigenicity in PCa models (He et al. 2007, Valencia et al. 2014, Minciacchi et al. 2017). In fact, gastric cancerassociated stromal methylation signature was found to be a determinant of epithelial tumor stage (Jiang et al. 2008). Methylation-sensitive SNP array analysis (MSNP) was used to compare DNA methylation in NAF and CAF cells. Fewer genes were found to have promoter hypermethylation in CAFs compared to NAF (Jiang et al. 2008). Aberrant DNA methylation pattern in CAFs that affected TGF- $\beta$ signaling was found to be prognostic for non-small-cell lung cancer patients (Vizoso et al. 2015). CAF in pancreatic ductal adenocarcinoma, associated with extensive connective tissue deposition, had a distinct methylation landscape that promote malignant growth and progression. Suppressor of cytokine signaling (SOCS) family gene, SOCS1 was identified as a prominent gene frequently methylated in pancreatic CAFs (Xiao et al. 2016). Conversely, the ADAM12 gene promoter was hypomethylated in pancreatic CAFs (Yu et al. 2012). Together, these data demonstrate stromal DNA methylation status can impact cancer progression.

In a noteworthy study, Albrengues et al. demonstrated that an epigenetic switch involving the leukemiainducible factor (LIF), a proinflammatory cytokine of IL-6 class secreted by cancer cells, reprograms human head and neck CAF into a state that supported cancer cell invasion via extracellular matrix (ECM) remodeling (Albrengues et al. 2015). They further showed that DNMT3B methylated CpG sites of the SHP-1 phosphatase promoter to downregulate SHP-1 expression, resulting in constitutive phosphorylation of JAK1. Thereafter JAK1/STAT3 signaling was sustained by maintenance methylation enzyme, DNMT1. This study provided a unique link of histone modification and DNA methylation in fibroblasts. The authors observed that DNMT inhibitor, 5-AzaDC, restored the expression of SHP-1, thereby decreasing JAK1/STAT3 activation, and tumor-inductive properties of the fibroblasts. All together, these studies demonstrated crucial role of DNA methylation activity of the tumor microenvironment provided sustained head and neck cancer proinvasive activity. Histone methylation is also crucial for fibroblast activation. Accordingly, Tyan et al. reported that the loss of EZH2 (enhancer of zeste homolog 2) caused promoterassociated histone H3K27 methylation at the ADAMTS1 gene (ADAM metallopeptidase with thrombospondin type 1 motif), accounting for its enhanced expression (Tyan et al. 2012). These studies supported the role of epigenetic modification in breast stromal fibroblasts in conferring a tumor-inductive phenotype. Apart from histone modification, non-histone chromatin remodeling gene, Hmga2 (High-mobility group AT-hook 2) has been identified as an epigenetic regulator in prostatic fibroblasts. Stromal-specific overexpression of Hmga2 in mouse fibroblasts was sufficient for the induction of multifocal prostatic intraepithelial neoplasia in adjacent prostatic epithelia (Zong et al. 2012). More research is needed to understand the underpinning mechanisms for the emergence of the stable CAF phenotype. Figure 2 illustrates general epigenetic changes involved in fibroblast which alter cancer epithelial communications and proliferations.

\section{Epigenetic silencing of RasGAPs: alternative route to Ras signaling activation in cancer}

Altered Ras signaling has achieved notoriety in contributing to tumorigenesis (Fernandez-Medarde \& Santos 2011). More than 30\% of all human neoplasms

This work is licensed under a Creative Commons Attribution 4.0 International License. ded from Bioscientifica.com at 04/26/2023 01:23:30PM 


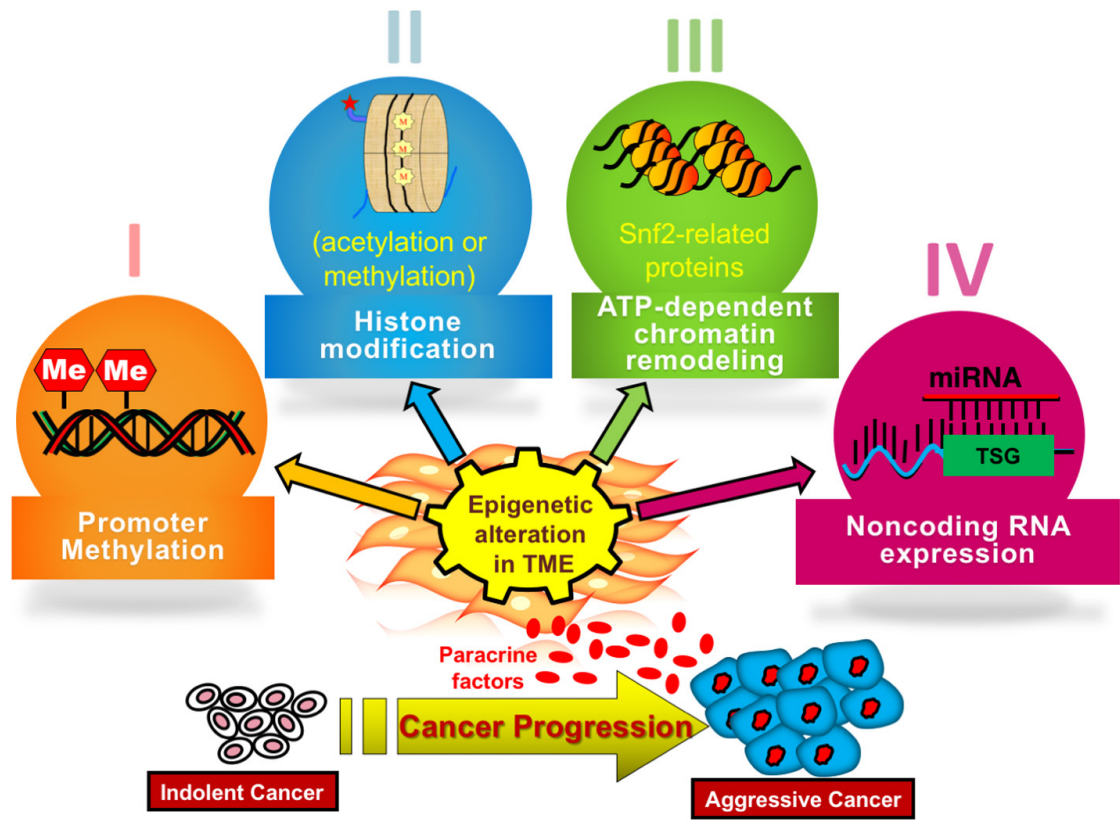

\section{Figure 2}

A general scheme of epigenetic changes in fibroblasts include four basic mechanisms: (I) promoter DNA modifications, (II) histone modifications, (III) chromatin remodeling with polycomb proteins, and (IV) aberrant expression of miRNA. These well-known epigenetic modifications taking place in the tumor microenvironment can lead to transcriptomic changes, that in-turn can be suppressive of promoting of tumor expansion in a paracrine manner. harbor an oncogenic form of Ras proteins, made up of a small family of three closely related proteins (K-Ras, H-Ras, or N-Ras) (Adjei 2001, Canevari et al. 2002). As GTPases, Ras proteins oscillate between an active GTP-bound and guanosine diphosphate (GDP)-bound inactive state. The RasGAP family of proteins inactivate Ras signaling by binding Ras and catalyzing Ras-GTP hydrolysis to Ras-GDP (King et al. 2013, Simanshu et al. 2017, Scheffzek \& Shivalingaiah 2019). The silencing of the RasGAP genes by promoter methylation results in the activation of RAS signaling and promote primary tumor development (Fernandez-Medarde \& Santos 2011, Simanshu et al. 2017). In addition, the inactivation of the RasGAP, RASAL1, in fibroblasts can contribute to renal and cardiac fibrosis (Bechtel et al. 2010, Xu et al. 2015). There are 14 RasGAP genes identified in the human genome (Bernards 2003). We performed Oncomine analysis to investigate the differences in the mRNA levels of different RasGAPs genes, between tumor and normal tissues in multiple cancer types (Fig. 3). The epigenetic regulation of RasGAP proteins that contribute to activation of Ras signaling and its implication in tumorigenesis is further discussed below.

DAB2IP is one of most well-studied RasGAPs in cancers, also known as AIP1 (ASK1-interacting protein). Several studies reported DAB2IP gene regulation through aberrant methylation in prostate, breast, lung, liver and gastrointestinal cancers (Chen et al. 2003, Dote et al. 2004, 2005, Yano et al. 2005). A DNA methylationbased study conducted in renal cell carcinoma identified DAB2IP promoter methylation as a practical prognostic biomarker. The $\mathrm{CpG}$ methylation biomarker is located upstream of the transcription start site of DAB2IP (DAB2IP CpG1). Pyrosequencing quantitative methylation assay of over 550 patient paraffin renal cancer tissue sections was used to establish a correlation between DAB2IP CpG1 methylation and overall survival (Wang et al. 2016). Similarly, DAB2IP promoter methylation and expression downregulation were identified to be associated with breast cancer lymph node metastasis (Dote et al. 2004). The restoration of DAB2IP expression by 5-acetazolamide-2-cytosine deoxyriboside (5azaDC, DNA demethylating agent) supported the epigenetic regulation of breast cancer progression (Dote et al. 2004). Methylation of DAB2IP exon 3 was associated with histone H3 di- and trimethyl H3-Lys27 (H3K27me2 and H3K27me3), a site known to be modified by EZH2 and recruitment of polycomb repressive complex 2 and histone deacetylases (Chen et al. 2003, Smits et al. 2012). The established tumor-suppressive role of DAB2IP has been extended to its role in angiogenesis inhibition and chemo/radiation sensitization, to reveal some Ras-independent effects of this RasGAP.

RASAL1 has been identified as a tumor suppressor, frequently silenced by promoter hypermethylation in numerous cancer types. For example, screening of 13 RasGAPs in 12 human thyroid cancer cell lines revealed epigenetic silencing of RASAL1 (Liu et al. 2013). Notably, treating these cell lines with 5azaDC restored RASAL1 expression. In another example, promoter hypermethylation of RASAL1 was found in colorectal cancers, interestingly frequently also associated with 
K-Ras mutational activation (Ohta et al. 2009). Ectopic expression of RASAL1 or using a DNA methylation inhibitor was found to reduce Ras signaling and colon cancer progression (Liu et al. 2005, Ohta et al. 2009). Likewise, RASAL1 promoter DNA hypermethylation in gastric cancer tumor tissues were greater than that in paired adjacent non-tumor tissues (Chen et al. 2013). Apart from DNA methyltransferases, there are also histone-modifying enzymes, which can play a role in the regulation of RASAL1. Brigette et al. revealed that treatment with histone deacetylase inhibitor (HDACi), belinostat (PXD101), led to a modest restoration of RASAL1 expression in HepG2 and Hep3b cell lines (Ma et al. 2010). For these diverse cancer types with RASAL1 epigenetic silencing, often associated with Rasdriven carcinogenesis, the added loss of the suppressor potentially super-activates the Ras signaling axis. In the same models, however, the restoration of RASAL1 expression was found to negate some of the effects of the endogenous Ras-activating mutations or amplification. Thus, epigenetically regulated RasGAP activity can be considered to be dominant over such genomic alterations of the Ras gene.

Epigenetic silencing of RASAL2 has demonstrated that it can function as a tumor and metastasis suppressor, in breast cancer, hepatocellular carcinoma, colorectal cancer (Jia et al. 2017), nasopharyngeal carcinoma, lung cancer, and ovarian cancer (McLaughlin et al. 2013, Feng et al. 2014, Huang et al. 2014, Li \& Li 2014, Stefanska et al. 2014, Wang et al. 2015, Yan et al. 2016, Olsen et al. 2017). Notably, promoter hypermethylation of RASAL2 and DAB2IP was identified in aggressive luminal $\mathrm{B}$ breast cancer (Olsen et al. 2017). Performing gain-of-function and loss-of-function studies, Hui et al. demonstrated that formation of new blood vessels was suppressed by RASAL2 via VEGFA downregulation in renal cell carcinoma metastasis (Hui et al. 2018). Further, the epigenetic silencing of RASAL2 was negatively correlated with the overall survival of renal cell carcinoma patients (Hui et al. 2018).

Unlike the other two RASAL family members, RASAL3 has not been considered a tumor suppressor in the

\begin{tabular}{|c|c|c|c|c|c|c|c|c|}
\hline \multirow{3}{*}{$\begin{array}{r}\text { Analysis Type by Cancer } \\
\text { Bladder Cancer }\end{array}$} & \multicolumn{8}{|c|}{ Cancer vs Normal ( $p$ value set to 0.05 ) } \\
\hline & \multicolumn{2}{|c|}{ RASAL1 } & \multicolumn{2}{|c|}{ RASAL2 } & \multicolumn{2}{|c|}{ RASAL3 } & \multicolumn{2}{|c|}{ DAB2IP } \\
\hline & 3 & 2 & 4 & 4 & & 1 & 5 & 7 \\
\hline Brain and CNS Cancer & 4 & 11 & 10 & 13 & 7 & 1 & 2 & 20 \\
\hline Breast Cancer & 7 & 9 & 28 & 6 & 13 & 3 & 3 & 27 \\
\hline Cervical Cancer & 1 & 4 & 4 & 4 & 1 & 1 & 4 & 5 \\
\hline Colorectal Cancer & 15 & 6 & 28 & 5 & 4 & 19 & 2 & 22 \\
\hline Esophageal Cancer & & 5 & 1 & 4 & 1 & & 1 & 9 \\
\hline Gastric Cancer & 4 & 7 & 21 & 4 & 3 & 5 & 4 & 2 \\
\hline Head and Neck Cancer & 9 & 11 & 7 & 14 & 1 & 3 & 3 & 18 \\
\hline Kidney Cancer & 7 & 4 & 10 & 11 & 4 & 1 & 13 & 4 \\
\hline Leukemia & 7 & 5 & 15 & 5 & 5 & 4 & 6 & 13 \\
\hline Liver Cancer & & 4 & 11 & 3 & & & 1 & 7 \\
\hline Lung Cancer & 8 & 1 & 13 & 7 & & 9 & 3 & 21 \\
\hline Lymphoma & 6 & 7 & 20 & 15 & 6 & 8 & 28 & 3 \\
\hline Melanoma & & 2 & 2 & 1 & 1 & & & 2 \\
\hline Myeloma & 2 & 2 & 4 & & 1 & & 1 & 7 \\
\hline Other Cancer & 11 & 2 & 7 & 12 & 6 & 1 & 8 & 6 \\
\hline Ovarian Cancer & 8 & 1 & 6 & 2 & 1 & 1 & 8 & 2 \\
\hline Pancreatic Cancer & 1 & 3 & 8 & 3 & & 3 & 7 & 1 \\
\hline Prostate Cancer & 3 & 1 & 6 & 4 & 2 & & 3 & 6 \\
\hline Sarcoma & & 8 & 4 & 6 & 2 & 1 & 2 & 10 \\
\hline Significant Unique Analyses & 96 & 93 & 208 & 123 & 58 & 61 & 104 & 191 \\
\hline Total Unique Analyses & \multicolumn{2}{|c|}{355} & \multicolumn{2}{|c|}{426} & \multicolumn{2}{|c|}{265} & \multicolumn{2}{|c|}{458} \\
\hline
\end{tabular}

Figure 3

The expression levels of human RASAL1, RASAL2, RASAL3 and DAB2IP are profiled across multiple cancer types, compared to normal tissue by Oncomine. The gene expression level differences between cancer and normal tissue are illustrated. The number of datasets in which statistically significant mRNA overexpression or underexpression was observed is indicated in red or blue boxes, respectively. The color intensity corresponds to the gene rank and magnitude of expression differences with a statistically significant threshold. https://erc.bioscientifica.com https://doi.org/10.1530/ERC-19-0347 (c) 2019 The authors Published by Bioscientifica Ltd. Printed in Great Britain
This work is licensed under a Creative Commons Attribution 4.0 International License. 
traditional sense, in terms of being silenced in tumor cells. The role of RASAL3 in immune cells have been recognized. Initially, the epigenetic silencing of Rasal3 was observed in canine B-cell lymphoma, identified by DNA methylome by genome-wide CpG microarray (Stefanska et al. 2014). Subsequently, a mouse model systemically knocking out Rasal3 resulted in reduced number of natural killer (NK) cells and diminished expression of interleukin-4 and interferon- $\gamma$ by the NK cells (Saito et al. 2015). The knockout of Rasal3 also results in reduced number of naïve $\mathrm{T}$ cells, demonstrating the role of RASAL3 in supporting cell survival (Muro et al. 2018). In light of the recognized importance of tumor immunity, there may be further justification for the restoration of RASAL3 expression, potentially through the use of HDAC inhibitors or DNAdemethylating agents. In fact, the current use and observed efficacy of such therapeutics may in part be due to their impact on RASAL3 on non-tumor cells. We reported RASAL3 promoter methylation, through RRBS sequencing analysis, is a crucial step in activating Ras signaling in prostatic CAF (Mishra et al. 2018). As described earlier, oncogene signaling in CAF can potentiate the expansion of adjacent cancer epithelia. Accordingly, we found that active Ras signaling in the CAF caused PCa epithelial proliferation and acquisition of a neuroendocrine phenotype. Interestingly, we further revealed that RASAL3 epigenetic silencing and Ras signaling activation in CAF was heightened by the androgen receptor antagonism, a mainstay in PCa therapy. It is important to note that PCa is not recognized as a Ras-driven cancer. Hormone signaling regulates oncogenic signaling mechanisms that stimulate the activation of fibroblasts, can cause therapeutic resistance of the adjacent epithelia in a paracrine manner.

\section{Enhanced macropinocytosis provide metabolic flexibility for tumor cells}

In Ras-driven cancers like pancreatic and glioblastoma, a process of uptake of albumin and other macromolecules from its surroundings, termed macropinocytosis occurs (Commisso et al. 2013, Muller-Greven et al. 2017). Subsequent albumin translocation to lysosomes generates amino acids. And as albumin is rich in glutamine, an outcome of macropinocytosis is glutamine efflux. For pancreatic cancer, the further metabolism of glutamine serves as a means of fueling cancer progression. However, we found that prostatic CAFs do not seem to metabolize the glutamine further (Mishra et al. 2018). Rather, glutamine gets secreted for its uptake by adjacent cancer epithelia, where it is metabolized to glutamate and enters the TCA cycle via $\alpha$-ketoglutarate. A key hurdle for cancer cells is to fulfill rising energy demand for the growing biomass in often nutrient-depleted conditions (DeBerardinis \& Chandel 2016). In order to meet energy/ biosynthetic demand, tumors have evolved tremendous capacity to reprogram pathways triggering nutrient acquisition. Metabolic reprogramming is recognized as one of the hallmarks of cancer (Hanahan \& Weinberg 2011) and explored as therapeutic targets (Altman et al. 2016, DeBerardinis \& Chandel 2016, Cluntun et al. 2017). We demonstrated that the uptake of glutamine by amino acid transporter (SLC1A5), as well the metabolism of glutamine to glutamate by glutaminase (GLS) was upregulated in the cancer epithelia in response to elevated concentrations of glutamine in the media (Mishra et al. 2018). Macropinocytosis is one of the important strategies that cancer cells use as an alternative nutrient acquisition pathway (Commisso et al. 2013, Zwartkruis \& Burgering 2013, Nakase et al. 2015, Wang et al. 2018). While the first microscopic observations of macropinocytosis in malignant cells was discovered in 1930s, its mechanistic understanding occurred in the last few years. The uptake of macromolecules through a specialized process of plasma membrane ruffling for the formation of endocytic macropinosomes that fuse into lysosomes is now an established process for anabolic metabolism for cancer cells (Recouvreux \& Commisso 2017, Wang et al. 2018). Apart from oncogenic Ras activation, phosphatidylinositol 3-kinase (PI3-kinase) and phosphatase and tensin homolog (PTEN) mutations found in cancer (Chalhoub \& Baker 2009) may also potentiate macropinocytosis as an adaptation to limiting nutrient availability (DeBerardinis \& Chandel 2016, Cluntun et al. 2017, Recouvreux \& Commisso 2017). However, in the case of PCa, the stromal co-evolution with the cancer epithelia involve epigenetic imprinting associated with RASAL3 silencing. This particular stromal reprogramming supports cancer progression via the induction of fibroblastic activation and secretion of glutamine.

The role of glutamine as a conditionally essential amino acid for cancer cells is well documented as a critical metabolite for nucleotide biosynthesis and anaplerosis. In addition, we found that incubation of PCa cells with glutamine resulted in the expression of neuroendocrine markers. We demonstrated that the uptake and metabolism of glutamine by SLC1A5 and GLS, respectively, was critical to the differentiation of prostate adenocarcinoma to the neuroendocrine phenotype. Neuroendocrine prostate cancer (NEPC) cells loose 


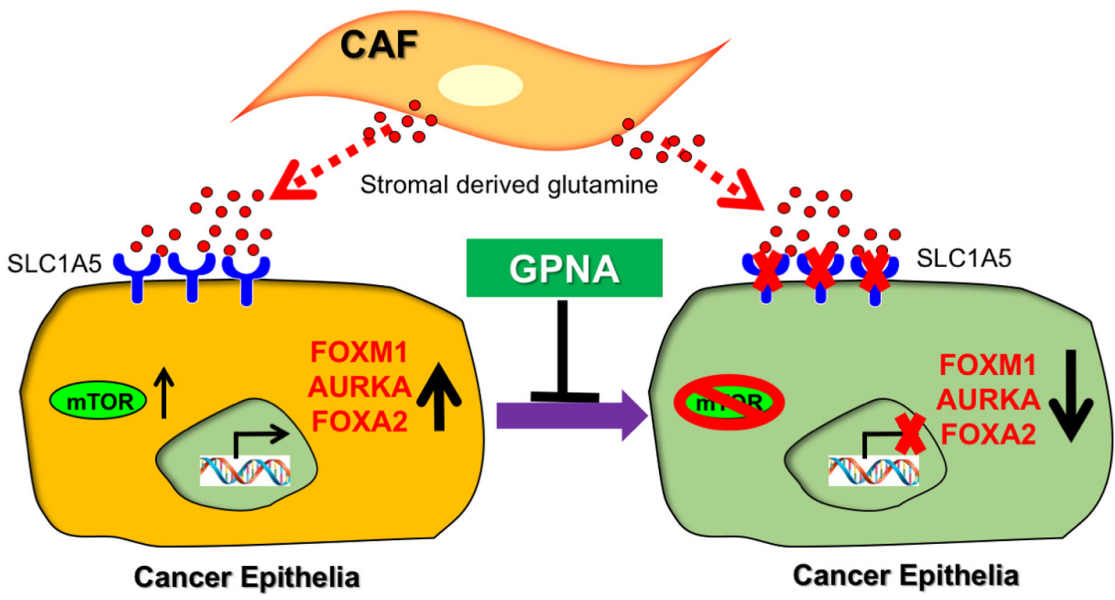

\section{Figure 4}

Proposed model of stromal inducedneuroendocrine prostate cancer (NEPC). Carcinoma-associated fibroblasts (CAFs)-derived glutamine that can be taken-up by glutamine transporter, SLC1A5, and result in elevated mTOR signaling. Typical disease markers including chromogranin A (CHGA), FOXM1 and FOXA2 are shown upregulated after glutamine uptake in response to mTOR signaling. Inhibition of glutamine uptake by using SLC1A5 inhibitor, GPNA, limit the expression of NEPC markers. The studies suggest the importance of glutamine in NEPC transdifferentiation of prostate adenocarcinoma (Mishra et al. 2018). granular structure and tend to have a small cell-like morphology characterized by the varying levels of expression of neuronal markers, including chromogranin A (CGA), synaptophysin (SYP), neurospecific enolase (NSE), and more recently T-Box brachyury (Blaschko et al. 1967, Schmechel et al. 1978, Wiedenmann et al. 1986, Pinto et al. 2016). De novo NEPC is one of the rarest form $(<1 \%)$ of the disease (Gupta \& Gupta 2017). However, in response to $\mathrm{AR}$ signaling inhibition and/or androgen deprivation therapy, transdifferentiation to NEPC can support rapid disease progression with universally poor outcome, with an overall 5-year survival rate of $12.6 \%$ (Beltran et al. 2014, Yadav et al. 2016). Importantly, the transdifferentiated NEPC does not necessarily exhibit all the characteristics of de novo NEPC (Beltran et al. 2012, 2014). For example, transdifferentiated NEPC often maintains responsiveness to androgens despite its resistance to AR signaling inhibitors. While its incidence in primary prostate cancers is exceedingly low, in metastatic castrate-resistant prostate cancers (CRPCs), its percentage goes up to 25-30\% (Gupta \& Gupta 2017). Paracrine glutamine signaling is a mechanism by which AR signaling inhibitors potentiate this phenotype. We validated this finding in PCa patients that were on androgen receptor signaling inhibitors and found that those patients that developed therapeutic resistance had significantly higher blood glutamine levels compared to those who remained sensitive to hormone therapy (Mishra et al. 2018).

\section{Therapeutic interventions in response to stromal co-evolution}

There is a need for better understanding of NEPC with the approval of more effective inhibitors of AR signaling (i.e. enzalutamide, apalutamide, darolutamide) for advanced PCa. Genomic characterization of transdifferentiated NEPC phenotypic tumors revealed recurrent amplifications of MYCN and AURKA as well as lesions of RB1 and TP53 (Beltran et al. 2011, Tan et al. 2014). For example, MYCN mutations are found in $40 \%$ of NEPCs, but only observed in 5\% of all other PCa (Beltran et al. 2011). However, expression of other recognized NEPC markers, CHGA, SYP, NCAM1, and ENO2, was heterogeneous. The role of biomarkers not only serve to characterize the tumor type, but may provide a clue as to an effective intervention. Aurora kinase (AURK) was a specifically targeted kinase for cancers driven by MYCN, such as NEPC, neuroblastoma, and hepatocellular carcinoma with significant efficacy in mouse models (Otto et al. 2009, Dauch et al. 2016, Lee et al. 2016). Since AURK was found to bind and stabilization of MYCN (Otto et al. 2009), its inhibition resulted in MYCN degradation and reduction in tumor volume in a model of NEPC (Lee et al. 2016). A subsequent phase II clinical trial for NEPC patients with a AURK inhibitor, alisertib, unfortunately did not meet its primary endpoint, but the subset of patients that exhibited elevated MYCN and AURK were found to gain significant clinical benefit (Beltran et al. 2019).

MYC amplification can contribute to the regulation of glutamine metabolism in prostate cancer. Cancers with MYC amplification exhibit elevated expression of amino acid transporters SLC1A5 and SLC38A5, as well as glutamine-metabolizing enzyme, GLS. Glutamine addiction of cancer cells can be exploited through the inhibition of amino acid transporters or inhibitors of glutamine metabolism. However, non-cancer cells are generally non-vulnerable to such glutamine deprivation (Chen \& Cui 2015, Altman et al. 2016, Still \& Yuneva 2017). 
Understanding of compensatory pathways of glutamine metabolism may improve the efficacy of cancer treatments. A sensor for abundant ATP includes the inhibition of AMP kinase, a known blocker of mTOR signaling. Thus, glutamine metabolism causes inhibition of the inhibitor of mTOR, resulting in mTOR activation and its downstream transcription factor FOXM1 in potentiating the expression of a number of NEPC-associated genes (Mishra et al. 2018). FOXM1 is a known master regulator of cancer metastasis, the expression of multiple stem cell genes, as well as MYCN and AURK (Raychaudhuri $\&$ Park 2011). Blocking GLS with BPTES (bis-2-(5-pheny lacetamido-1,3,4-thiadiazol-2-yl)ethyl sulfide) inhibited NEPC transdifferentiation (Mishra et al. 2018) (Fig. 4). CB-839 is a glutaminase inhibitor that is shown to be safe in phase I clinical trials and considerably more potent than BPTES. Blocking glutamine uptake by using GPNA (L- $\gamma$-glutamyl-p-nitroanilide), a SLC1A5 inhibitor was effective in reducing tumor growth in the context of a commonly administered androgen receptor signaling inhibitor, enzalutamide (Mishra et al. 2018). As metastatic castrate-resistant prostate tumors have elevated available glutamine in circulation and its uptake can potentiate resistance to current AR signaling inhibition, a richer understanding of this pathway would contribute to better PCa treatment strategies.

\section{Declaration of interest}

The authors declare that there is no conflict of interest that could be perceived as prejudicing the impartiality of this review.

\section{Funding}

This work was supported by the Department of Defense (W81XWH-19-1-0388) and Veterans Affairs (I01BX001040) to N A B, as well as a Manipal University Jaipur, Enhanced Seed grant (EF/2018-19/QE04-11) to $\mathrm{R}$ M.

\section{References}

Adjei AA 2001 Blocking oncogenic Ras signaling for cancer therapy. Journal of the National Cancer Institute 93 1062-1074. (https://doi. org/10.1093/jnci/93.14.1062)

Albrengues J, Bertero T, Grasset E, Bonan S, Maiel M, Bourget I, Philippe C, Herraiz Serrano C, Benamar S, Croce O, et al. 2015 Epigenetic switch drives the conversion of fibroblasts into proinvasive cancer-associated fibroblasts. Nature Communications 6 10204. (https://doi.org/10.1038/ncomms10204)

Allocati N, Masulli M, Di Ilio C \& Federici L 2018 Glutathione transferases: substrates, inhibitors and pro-drugs in cancer and neurodegenerative diseases. Oncogenesis 7 8. (https://doi.org/10.1038/ s41389-017-0025-3)
Altman BJ, Stine ZE \& Dang CV 2016 From Krebs to clinic: glutamine metabolism to cancer therapy. Nature Reviews: Cancer 16749. (https://doi.org/10.1038/nrc.2016.114)

Banerjee J, Mishra R, Li X, Jackson 2nd RS, Sharma A \& Bhowmick NA 2014 A reciprocal role of prostate cancer on stromal DNA damage. Oncogene 33 4924-4931. (https://doi.org/10.1038/onc.2013.431)

Bechtel W, McGoohan S, Zeisberg EM, Muller GA, Kalbacher H, Salant DJ, Muller CA, Kalluri R \& Zeisberg M 2010 Methylation determines fibroblast activation and fibrogenesis in the kidney. Nature Medicine 16 544-550.

Beltran H, Rickman DS, Park K, Chae SS, Sboner A, MacDonald TY, Wang Y, Sheikh KL, Terry S, Tagawa ST, et al. 2011 Molecular characterization of neuroendocrine prostate cancer and identification of new drug targets. Cancer Discovery 1 487-495. (https://doi. org/10.1158/2159-8290.CD-11-0130)

Beltran H, Tagawa ST, Park K, MacDonald T, Milowsky MI, Mosquera JM, Rubin MA \& Nanus DM 2012 Challenges in recognizing treatmentrelated neuroendocrine prostate cancer. Journal of Clinical Oncology 30 e386-e389. (https://doi.org/10.1200/JCO.2011.41.5166)

Beltran H, Tomlins S, Aparicio A, Arora V, Rickman D, Ayala G, Huang J, True L, Gleave ME, Soule H, et al. 2014 Aggressive variants of castration-resistant prostate cancer. Clinical Cancer Research 202846 2850. (https://doi.org/10.1158/1078-0432.CCR-13-3309)

Beltran H, Oromendia C, Danila DC, Montgomery B, Hoimes C, Szmulewitz RZ, Vaishampayan U, Armstrong AJ, Stein M, Pinski J, et al. 2019 A phase II trial of the aurora kinase a inhibitor alisertib for patients with castration-resistant and neuroendocrine prostate cancer: efficacy and biomarkers. Clinical Cancer Research 25 43-51. (https://doi.org/10.1158/1078-0432.CCR-18-1912)

Bernards A 2003 GAPs galore! A survey of putative Ras superfamily GTPase activating proteins in man and Drosophila. Biochimica et Biophysica Acta 1603 47-82.

Bhowmick NA, Chytil A, Plieth D, Gorska AE, Dumont N, Shappell S, Washington MK, Neilson EG \& Moses HL 2004 TGF-beta signaling in fibroblasts modulates the oncogenic potential of adjacent epithelia. Science 303 848-851. (https://doi.org/10.1126/ science.1090922)

Bianchi-Frias D, Basom R, Delrow JJ, Coleman IM, Dakhova O, Qu X, Fang M, Franco OE, Ericson NG, Bielas JH, et al. 2016 Cells comprising the prostate cancer microenvironment lack recurrent clonal somatic genomic aberrations. Molecular Cancer Research 14 374-384. (https://doi.org/10.1158/1541-7786.MCR-15-0330)

Blaschko H, Comline RS, Schneider FH, Silver M \& Smith AD 1967 Secretion of a chromaffin granule protein, chromogranin, from the adrenal gland after splanchnic stimulation. Nature 215 58-59. (https://doi.org/10.1038/215058a0)

Bock C, Tomazou EM, Brinkman AB, Muller F, Simmer F, Gu H, Jager N, Gnirke A, Stunnenberg HG \& Meissner A 2010 Quantitative comparison of genome-wide DNA methylation mapping technologies. Nature Biotechnology 28 1106-1114. (https://doi. org/10.1038/nbt.1681)

Buysse K, Riemersma M, Powell G, van Reeuwijk J, Chitayat D, Roscioli T, Kamsteeg EJ, van den Elzen C, van Beusekom E, Blaser S, et al. 2013 Missense mutations in beta-1,3-N-acetylglucosam inyltransferase 1 (B3GNT1) cause Walker-Warburg syndrome. Human Molecular Genetics 22 1746-1754.

Canevari S, Biocca S \& Figini M 2002 Re: blocking oncogenic Ras signaling for cancer therapy. Journal of the National Cancer Institute 94 1031-1032; author reply 1032. (https://doi.org/10.1093/ jnci/94.13.1031)

Cao Y, Lin SH, Wang Y, Chin YE, Kang L \& Mi J 2017 Glutamic pyruvate transaminase GPT2 promotes tumorigenesis of breast cancer cells by activating sonic hedgehog signaling. Theranostics 7 3021-3033.

Chaffer CL \& Weinberg RA 2011 A perspective on cancer cell metastasis. Science 331 1559-1564. (https://doi.org/10.1126/ science.1203543)

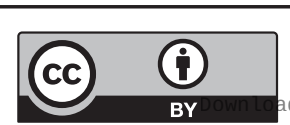

This work is licensed under a Creative Commons Attribution 4.0 International License. ded from Bioscientifica.com at 04/26/2023 01:23:30PM 
Chalhoub N \& Baker SJ 2009 PTEN and the PI3-kinase pathway in cancer. Annual Review of Pathology 4 127-150. (https://doi. org/10.1146/annurev.pathol.4.110807.092311)

Chen L \& Cui H 2015 Targeting glutamine induces apoptosis: a cancer therapy approach. International Journal of Molecular Sciences $\mathbf{1 6}$ 22830-22855. (https://doi.org/10.3390/ijms160922830)

Chen H, Toyooka S, Gazdar AF \& Hsieh JT 2003 Epigenetic regulation of a novel tumor suppressor gene (hDAB2IP) in prostate cancer cell lines. Journal of Biological Chemistry 278 3121-3130. (https://doi. org/10.1074/jbc.M208230200)

Chen H, Pan Y, Cheng ZY, Wang Z, Liu Y, Zhao ZJ \& Fan H 2013 Hypermethylation and clinicopathological significance of RASAL1 gene in gastric cancer. Asian Pacific Journal of Cancer Prevention 14 6261-6265. (https://doi.org/10.7314/apjcp.2013.14.11.6261)

Cheng N, Bhowmick NA, Chytil A, Gorksa AE, Brown KA, Muraoka R, Arteaga CL, Neilson EG, Hayward SW \& Moses HL 2005 Loss of TGFbeta type II receptor in fibroblasts promotes mammary carcinoma growth and invasion through upregulation of TGF-alpha-, MSP- and HGF-mediated signaling networks. Oncogene 24 5053-5068. (https:// doi.org/10.1038/sj.onc.1208685)

Christensen MV, Hogdall CK, Jochumsen KM \& Hogdall EVS 2018 Annexin A2 and cancer: a systematic review. International Journal of Oncology 52 5-18.

Clark SJ, Harrison J, Paul CL \& Frommer M 1994 High sensitivity mapping of methylated cytosines. Nucleic Acids Research 22 2990-2997. (https://doi.org/10.1093/nar/22.15.2990)

Cluntun AA, Lukey MJ, Cerione RA \& Locasale JW 2017 Glutamine metabolism in cancer: understanding the heterogeneity. Trends in Cancer 3 169-180. (https://doi.org/10.1016/j.trecan.2017.01.005)

Commisso C, Davidson SM, Soydaner-Azeloglu RG, Parker SJ, Kamphorst JJ, Hackett S, Grabocka E, Nofal M, Drebin JA, Thompson CB, et al. 2013 Macropinocytosis of protein is an amino acid supply route in Ras-transformed cells. Nature 497 633-637. (https://doi.org/10.1038/nature12138)

Dauch D, Rudalska R, Cossa G, Nault JC, Kang TW, Wuestefeld T, Hohmeyer A, Imbeaud S, Yevsa T, Hoenicke L, et al. 2016 A MYCaurora kinase A protein complex represents an actionable drug target in p53-altered liver cancer. Nature Medicine 22 744-753. (https://doi. org/10.1038/nm.4107)

DeBerardinis RJ \& Chandel NS 2016 Fundamentals of cancer metabolism. Science Advances 2 e1600200. (https://doi.org/10.1126/ sciadv.1600200)

Delfino FJ, Stevenson H \& Smithgall TE 2006 A growth-suppressive function for the c-fes protein-tyrosine kinase in colorectal cancer. Journal of Biological Chemistry 281 8829-8835.

Dey P 2011 Epigenetic changes in tumor microenvironment. Indian Journal of Cancer 48 507-512. (https://doi.org/10.4103/0019509X.92246)

Dote H, Toyooka S, Tsukuda K, Yano M, Ouchida M, Doihara H, Suzuki M, Chen H, Hsieh JT, Gazdar AF, et al. 2004 Aberrant promoter methylation in human DAB2 interactive protein (hDAB2IP) gene in breast cancer. Clinical Cancer Research 10 2082-2089. (https://doi.org/10.1158/1078-0432.CCR-03-0236)

Dote H, Toyooka S, Tsukuda K, Yano M, Ota T, Murakami M, Naito M, Toyota M, Gazdar AF \& Shimizu N 2005 Aberrant promoter methylation in human DAB2 interactive protein (hDAB2IP) gene in gastrointestinal tumour. British Journal of Cancer 92 1117-1125. (https://doi.org/10.1038/sj.bjc.6602458)

Dumont N, Wilson MB, Crawford YG, Reynolds PA, Sigaroudinia M \& Tlsty TD 2008 Sustained induction of epithelial to mesenchymal transition activates DNA methylation of genes silenced in basal-like breast cancers. PNAS 105 14867-14872. (https://doi.org/10.1073/ pnas.0807146105)

Eads CA, Nickel AE \& Laird PW 2002 Complete genetic suppression of polyp formation and reduction of CpG-island hypermethylation in Apc(Min/+) Dnmt1-hypomorphic mice. Cancer Research 62 1296-1299.
Egger G, Jeong S, Escobar SG, Cortez CC, Li TW, Saito Y, Yoo CB, Jones PA \& Liang G 2006 Identification of DNMT1 (DNA methyltransferase 1) hypomorphs in somatic knockouts suggests an essential role for DNMT1 in cell survival. PNAS 103 14080-14085. (https://doi.org/10.1073/pnas.0604602103)

El-Osta A \& Wolffe AP 2000 DNA methylation and histone deacetylation in the control of gene expression: basic biochemistry to human development and disease. Gene Expression 9 63-75. (https://doi. org/10.3727/000000001783992731)

Feng M, Bao Y, Li Z, Li J, Gong M, Lam S, Wang J, Marzese DM, Donovan N, Tan EY, et al. 2014 RASAL2 activates RAC1 to promote triple-negative breast cancer progression. Journal of Clinical Investigation 124 5291-5304. (https://doi.org/10.1172/JCI76711)

Fernandez-Medarde A \& Santos E 2011 Ras in cancer and developmental diseases. Genes and Cancer 2 344-358. (https://doi. org/10.1177/1947601911411084)

Fiori ME, Di Franco S, Villanova L, Bianca P, Stassi G \& De Maria R 2019 Cancer-associated fibroblasts as abettors of tumor progression at the crossroads of EMT and therapy resistance. Molecular Cancer 1870. (https://doi.org/10.1186/s12943-019-0994-2)

Gascard P \& Tlsty TD 2016 Carcinoma-associated fibroblasts: orchestrating the composition of malignancy. Genes and Development 30 1002-1019. (https://doi.org/10.1101/gad.279737.116)

Goll MG, Kirpekar F, Maggert KA, Yoder JA, Hsieh CL, Zhang X, Golic KG, Jacobsen SE \& Bestor TH 2006 Methylation of tRNAAsp by the DNA methyltransferase homolog Dnmt2. Science 311 395-398. (https://doi.org/10.1126/science.1120976)

Gordetsky J \& Epstein J 2016 Grading of prostatic adenocarcinoma: current state and prognostic implications. Diagnostic Pathology 1125. (https://doi.org/10.1186/s13000-016-0478-2)

Gou WF, Sun HZ, Zhao S, Niu ZF, Mao XY, Takano Y \& Zheng HC 2014 Downregulated inhibitor of growth 3 (ING3) expression during colorectal carcinogenesis. Indian Journal of Medical Research 139 561-567.

Gupta K \& Gupta S 2017 Neuroendocrine differentiation in prostate cancer: key epigenetic players. Translational Cancer Research 6 S104-S108. (https://doi.org/10.21037/tcr.2017.01.20)

Hanahan D \& Weinberg RA 2000 The hallmarks of cancer. Cell 100 57-70. (https://doi.org/10.1016/s0092-8674(00)81683-9)

Hanahan D \& Weinberg RA 2011 Hallmarks of cancer: the next generation. Cell 144 646-674. (https://doi.org/10.1016/j. cell.2011.02.013)

Harris RA, Wang T, Coarfa C, Nagarajan RP, Hong C, Downey SL, Johnson BE, Fouse SD, Delaney A, Zhao Y, et al. 2010 Comparison of sequencing-based methods to profile DNA methylation and identification of monoallelic epigenetic modifications. Nature Biotechnology 28 1097-1105. (https://doi.org/10.1038/nbt.1682)

Hayward SW, Wang Y, Cao M, Hom YK, Zhang B, Grossfeld GD, Sudilovsky D \& Cunha GR 2001 Malignant transformation in a nontumorigenic human prostatic epithelial cell line. Cancer Research $618135-8142$.

He Y, Franco OE, Jiang M, Williams K, Love HD, Coleman IM, Nelson PS \& Hayward SW 2007 Tissue-specific consequences of cyclin D1 overexpression in prostate cancer progression. Cancer Research 67 8188-8197. (https://doi.org/10.1158/0008-5472.CAN-07-0418)

Heinecke JL, Ridnour LA, Cheng RY, Switzer CH, Lizardo MM, Khanna C, Glynn SA, Hussain SP, Young HA, Ambs S, et al. 2014 Tumor microenvironment-based feed-forward regulation of NOS2 in breast cancer progression. PNAS 111 6323-6328.

Hill R, Song Y, Cardiff RD \& Van Dyke T 2005 Selective evolution of stromal mesenchyme with p53 loss in response to epithelial tumorigenesis. Cell 123 1001-1011. (https://doi.org/10.1016/j. cell.2005.09.030)

Honeywell RJ, Sarkisjan D, Kristensen MH, de Klerk DJ \& Peters GJ 2018 DNA methyltransferases expression in normal tissues and various human cancer cell lines, xenografts and tumors. Nucleosides,

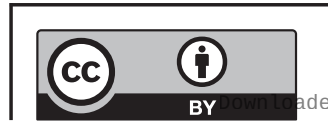

This work is licensed under a Creative Commons Attribution 4.0 International License. 
Nucleotides and Nucleic Acids 37 696-708. (https://doi.org/10.1080/15 257770.2018.1498516)

Hu M, Yao J, Cai L, Bachman KE, van den Brule F, Velculescu V \& Polyak K 2005 Distinct epigenetic changes in the stromal cells of breast cancers. Nature Genetics 37 899-905. (https://doi.org/10.1038/ ng1596)

Huang Y, Zhao M, Xu H, Wang K, Fu Z, Jiang Y \& Yao Z 2014 RASAL2 down-regulation in ovarian cancer promotes epithelial-mesenchymal transition and metastasis. Oncotarget 5 6734-6745. (https://doi. org/10.18632/oncotarget.2244)

Hui K, Yue Y, Wu S, Gu Y, Guan B, Wang X, Hsieh JT, Chang LS, He D \& Wu K 2018 The expression and function of RASAL2 in renal cell carcinoma angiogenesis. Cell Death and Disease 9 881. (https://doi. org/10.1038/s41419-018-0898-x)

Jeong HM, Han J, Lee SH, Park HJ, Lee HJ, Choi JS, Lee YM, Choi YL, Shin YK \& Kwon MJ 2017 ESRP1 is overexpressed in ovarian cancer and promotes switching from mesenchymal to epithelial phenotype in ovarian cancer cells. Oncogenesis 6 e389.

Jia Z, Liu W, Gong L \& Xiao Z 2017 Downregulation of RASAL2 promotes the proliferation, epithelial-mesenchymal transition and metastasis of colorectal cancer cells. Oncology Letters 13 1379-1385. (https://doi.org/10.3892/ol.2017.5581)

Jiang L, Gonda TA, Gamble MV, Salas M, Seshan V, Tu S, Twaddell WS, Hegyi P, Lazar G, Steele I, et al. 2008 Global hypomethylation of genomic DNA in cancer-associated myofibroblasts. Cancer Research 68 9900-9908. (https://doi.org/10.1158/0008-5472.CAN-08-1319)

Jin B \& Robertson KD 2013 DNA methyltransferases, DNA damage repair, and cancer. Advances in Experimental Medicine and Biology $\mathbf{7 5 4}$ 3-29. (https://doi.org/10.1007/978-1-4419-9967-2_1)

Kalluri R 2016 The biology and function of fibroblasts in cancer. Nature Reviews: Cancer 16 582-598. (https://doi.org/10.1038/nrc.2016.73)

Kim TW, Kang YK, Park ZY, Kim YH, Hong SW, Oh SJ, Sohn HA, Yang SJ, Jang YJ, Lee DC, et al. 2014 SH3RF2 functions as an oncogene by mediating PAK4 protein stability. Carcinogenesis $\mathbf{3 5}$ 624-634.

King PD, Lubeck BA \& Lapinski PE 2013 Nonredundant functions for Ras GTPase-activating proteins in tissue homeostasis. Science Signaling 6 re1. (https://doi.org/10.1126/scisignal.2003669)

Koguchi T, Tanikawa C, Mori J, Kojima Y \& Matsuda K 2016 Regulation of myo-inositol biosynthesis by p53-ISYNA1 pathway. International Journal of Oncology 48 2415-2424.

Land H, Parada LF \& Weinberg RA 1983 Tumorigenic conversion of primary embryo fibroblasts requires at least two cooperating oncogenes. Nature 304 596-602. (https://doi.org/10.1038/304596a0)

Langenkamp E, Zhang L, Lugano R, Huang H, Elhassan TE, Georganaki M, Bazzar W, Loof J, Trendelenburg G, Essand M, et al. 2015 Elevated expression of the C-type lectin CD93 in the glioblastoma vasculature regulates cytoskeletal rearrangements that enhance vessel function and reduce host survival. Cancer Research $\mathbf{7 5}$ $4504-4516$.

LeBleu VS \& Kalluri R 2018 A peek into cancer-associated fibroblasts: origins, functions and translational impact. Disease Models and Mechanisms 11. (https://doi.org/10.1242/dmm.029447)

Lee JS 2007 GSTP1 promoter hypermethylation is an early event in breast carcinogenesis. Virchows Archiv 450 637-642. (https://doi. org/10.1007/s00428-007-0421-8)

Lee WH, Morton RA, Epstein JI, Brooks JD, Campbell PA, Bova GS, Hsieh WS, Isaacs WB \& Nelson WG 1994 Cytidine methylation of regulatory sequences near the pi-class glutathione S-transferase gene accompanies human prostatic carcinogenesis. PNAS 91 1173311737. (https://doi.org/10.1073/pnas.91.24.11733)

Lee JK, Phillips JW, Smith BA, Park JW, Stoyanova T, McCaffrey EF, Baertsch R, Sokolov A, Meyerowitz JG, Mathis C, et al. 2016 N-Myc drives neuroendocrine prostate cancer initiated from human prostate epithelial cells. Cancer Cell 29 536-547. (https://doi.org/10.1016/j. ccell.2016.03.001)
Li N \& Li S 2014 RASAL2 promotes lung cancer metastasis through epithelial-mesenchymal transition. Biochemical and Biophysical Research Communications 455 358-362. (https://doi.org/10.1016/j. bbrc.2014.11.020)

Li H, Fan X, Kovi RC, Jo Y, Moquin B, Konz R, Stoicov C, Kurt-Jones E, Grossman SR, Lyle S, et al. 2007 Spontaneous expression of embryonic factors and $\mathrm{p} 53$ point mutations in aged mesenchymal stem cells: a model of age-related tumorigenesis in mice. Cancer Research 67 10889-10898. (https://doi.org/10.1158/0008-5472.CAN07-2665)

Li H, Wang Y, Lu Y \& Li F 2019 Annexin A2 interacting with ELMO1 regulates HCC chemotaxis and metastasis. Life Sciences 222 168-174.

Lin YH, Zhen YY, Chien KY, Lee IC, Lin WC, Chen MY \& Pai LM 2017 LIMCH1 regulates nonmuscle myosin-II activity and suppresses cell migration. Molecular and Cellular Biology 28 1054-1065.

Liu Q, Walker SA, Gao D, Taylor JA, Dai YF, Arkell RS, Bootman MD, Roderick HL, Cullen PJ \& Lockyer PJ 2005 Capri and RASAL impose different modes of information processing on Ras due to contrasting temporal filtering of Ca2+. Journal of Cell Biology 170 183-190. (https://doi.org/10.1083/jcb.200504167)

Liu D, Yang C, Bojdani E, Murugan AK \& Xing M 2013 Identification of RASAL1 as a major tumor suppressor gene in thyroid cancer. Journal of the National Cancer Institute 105 1617-1627. (https://doi. org/10.1093/jnci/djt249)

Lo PK \& Zhou Q 2018 Emerging techniques in single-cell epigenomics and their applications to cancer research. Journal of Clinical Genomics 1 [epub]. (https://doi.org/10.4172/JCG.1000103)

Lopes BA, Meyer C, Barbosa TC, Zur Stadt U, Horstmann M, Venn NC, Heatley S, White DL, Sutton R, Pombo-de-Oliveira MS, et al. 2016 COBL is a novel hotspot for IKZF1 deletions in childhood acute lymphoblastic leukemia. Oncotarget 7 53064-53073.

Luczak MW \& Jagodzinski PP 2006 The role of DNA methylation in cancer development. Folia Histochemica and Cytobiologica $\mathbf{4 4}$ $143-154$.

Ma BB, Sung F, Tao Q, Poon FF, Lui VW, Yeo W, Chan SL \& Chan AT 2010 The preclinical activity of the histone deacetylase inhibitor PXD101 (belinostat) in hepatocellular carcinoma cell lines. Investigational New Drugs 28 107-114. (https://doi.org/10.1007/ s10637-009-9219-7)

Maeda M, Takeshima H, Iida N, Hattori N, Yamashita S, Moro H, Yasukawa Y, Nishiyama K, Hashimoto T, Sekine S, et al. 2019 Cancer cell niche factors secreted from cancer-associated fibroblast by loss of H3K27me3. Gut [epub]. (https://doi.org/10.1136/ gutjnl-2018-317645)

McLaughlin SK, Olsen SN, Dake B, De Raedt T, Lim E, Bronson RT, Beroukhim R, Polyak K, Brown M, Kuperwasser C, et al. 2013 The RasGAP gene, RASAL2, is a tumor and metastasis suppressor. Cancer Cell 24 365-378. (https://doi.org/10.1016/j.ccr.2013.08.004)

Mi S, Li Z, Chen P, He C, Cao D, Elkahloun A, Lu J, Pelloso LA, Wunderlich M, Huang H, et al. 2010 Aberrant overexpression and function of the miR-17-92 cluster in MLL-rearranged acute leukemia. PNAS 107 3710-3715. (https://doi.org/10.1073/pnas.0914900107)

Minciacchi VR, Spinelli C, Reis-Sobreiro M, Cavallini L, You S, Zandian M, Li X, Mishra R, Chiarugi P, Adam RM, et al. 2017 MYC mediates large oncosome-induced fibroblast reprogramming in prostate cancer. Cancer Research 77 2306-2317. (https://doi. org/10.1158/0008-5472.CAN-16-2942)

Mishra R, Haldar S, Placencio V, Madhav A, Rohena-Rivera K, Agarwal P, Duong F, Angara B, Tripathi M, Liu Z, et al. 2018 Stromal epigenetic alterations drive metabolic and neuroendocrine prostate cancer reprogramming. Journal of Clinical Investigation 128 4472-4484. (https://doi.org/10.1172/JCI99397)

Moller-Levet CS, Betts GN, Harris AL, Homer JJ, West CM \& Miller CJ 2009 Exon array analysis of head and neck cancers identifies a hypoxia related splice variant of LAMA3 associated with a poor prognosis. PLoS Computational Biology 5 e1000571.

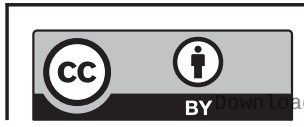

This work is licensed under a Creative Commons Attribution 4.0 International License. ded from Bioscientifica.com at 04/26/2023 01:23:30PM 
Moore LD, Le T \& Fan G 2013 DNA methylation and its basic function. Neuropsychopharmacology 38 23-38. (https://doi.org/10.1038/ npp.2012.112)

Muller-Greven G, Carlin CR, Burgett ME, Ahluwalia MS, Lauko A, Nowacki AS, Herting CJ, Qadan MA, Bredel M, Toms SA, et al. 2017 Macropinocytosis of bevacizumab by glioblastoma cells in the perivascular niche affects their survival. Clinical Cancer Research $\mathbf{2 3}$ 7059-7071. (https://doi.org/10.1158/1078-0432.CCR-17-0249)

Mulligan P, Westbrook TF, Ottinger M, Pavlova N, Chang B, Macia E, Shi YJ, Barretina J, Liu J, Howley PM, et al. 2008 CDYL bridges REST and histone methyltransferases for gene repression and suppression of cellular transformation. Molecular Cell 32 718-726.

Muro R, Nitta T, Kitajima M, Okada T \& Suzuki H 2018 Rasal3-mediated $\mathrm{T}$ cell survival is essential for inflammatory responses. Biochemical and Biophysical Research Communications 496 25-30. (https://doi. org/10.1016/j.bbrc.2017.12.159)

Nakase I, Kobayashi NB, Takatani-Nakase T \& Yoshida T 2015 Active macropinocytosis induction by stimulation of epidermal growth factor receptor and oncogenic Ras expression potentiates cellular uptake efficacy of exosomes. Scientific Reports 5 10300. (https://doi. org/10.1038/srep10300)

Ohta M, Seto M, Ijichi H, Miyabayashi K, Kudo Y, Mohri D, Asaoka Y, Tada M, Tanaka Y, Ikenoue T, et al. 2009 Decreased expression of the RAS-GTPase activating protein RASAL1 is associated with colorectal tumor progression. Gastroenterology 136 206-216. (https://doi. org/10.1053/j.gastro.2008.09.063)

Okano M, Xie S \& Li E 1998 Cloning and characterization of a family of novel mammalian DNA (cytosine-5) methyltransferases. Nature Genetics 19 219-220. (https://doi.org/10.1038/890)

Okano M, Bell DW, Haber DA \& Li E 1999 DNA methyltransferases Dnmt3a and Dnmt3b are essential for de novo methylation and mammalian development. Cell 99 247-257. (https://doi.org/10.1016/ s0092-8674(00)81656-6)

Oliphant MUJ, Vincent MY, Galbraith MD, Pandey A, Zaberezhnyy V, Rudra P, Johnson KR, Costello JC, Ghosh D, DeGregori J, et al. 2019 SIX2 mediates late-stage metastasis via direct regulation of SOX2 and induction of a cancer stem cell program. Cancer Research 79 720-734.

Olsen SN, Wronski A, Castano Z, Dake B, Malone C, De Raedt T, Enos M, DeRose YS, Zhou W, Guerra S, et al. 2017 Loss of RasGAP tumor suppressors underlies the aggressive nature of luminal B breast cancers. Cancer Discovery 7 202-217. (https://doi. org/10.1158/2159-8290.CD-16-0520)

Olumi AF, Grossfeld GD, Hayward SW, Carroll PR, Tlsty TD \& Cunha GR 1999 Carcinoma-associated fibroblasts direct tumor progression of initiated human prostatic epithelium. Cancer Research 59 5002-5011.

Otto T, Horn S, Brockmann M, Eilers U, Schuttrumpf L, Popov N, Kenney AM, Schulte JH, Beijersbergen R, Christiansen H, et al. 2009 Stabilization of N-Myc is a critical function of Aurora A in human neuroblastoma. Cancer Cell 15 67-78. (https://doi.org/10.1016/j. ccr.2008.12.005)

Pauken KE, Sammons MA, Odorizzi PM, Manne S, Godec J, Khan O, Drake AM, Chen Z, Sen DR, Kurachi M, et al. 2016 Epigenetic stability of exhausted T cells limits durability of reinvigoration by PD-1 blockade. Science 354 1160-1165. (https://doi.org/10.1126/ science.aaf2807)

Pavlova NN, Pallasch C, Elia AE, Braun CJ, Westbrook TF, Hemann M \& Elledge SJ 2013 A role for PVRL4-driven cell-cell interactions in tumorigenesis. eLife 2 e00358.

Perino M \& Veenstra GJ 2016 Chromatin control of developmental dynamics and plasticity. Developmental Cell 38 610-620. (https://doi. org/10.1016/j.devcel.2016.08.004)

Pidsley R, Lawrence MG, Zotenko E, Niranjan B, Statham A, Song J, Chabanon RM, Qu W, Wang H, Richards M, et al. 2018 Enduring epigenetic landmarks define the cancer microenvironment. Genome Research 28 625-638. (https://doi.org/10.1101/gr.229070.117)
Pinto F, Pertega-Gomes N, Vizcaino JR, Andrade RP, Carcano FM \& Reis RM 2016 Brachyury as a potential modulator of androgen receptor activity and a key player in therapy resistance in prostate cancer. Oncotarget 7 28891-28902. (https://doi.org/10.18632/ oncotarget.8499)

Placencio VR, Sharif-Afshar AR, Li X, Huang H, Uwamariya C, Neilson EG, Shen MM, Matusik RJ, Hayward SW \& Bhowmick NA 2008 Stromal transforming growth factor-beta signaling mediates prostatic response to androgen ablation by paracrine Wnt activity. Cancer Research 68 4709-4718. (https://doi.org/10.1158/0008-5472. CAN-07-6289)

Plava J, Cihova M, Burikova M, Matuskova M, Kucerova L \& Miklikova S 2019 Recent advances in understanding tumor stroma-mediated chemoresistance in breast cancer. Molecular Cancer 18 67. (https:// doi.org/10.1186/s12943-019-0960-z)

Qiu W, Hu M, Sridhar A, Opeskin K, Fox S, Shipitsin M, Trivett M, Thompson ER, Ramakrishna M, Gorringe KL, et al. 2008 No evidence of clonal somatic genetic alterations in cancer-associated fibroblasts from human breast and ovarian carcinomas. Nature Genetics 40 650655. (https://doi.org/10.1038/ng.117)

Quail DF \& Joyce JA 2017 The microenvironmental landscape of brain tumors. Cancer Cell 31 326-341. (https://doi.org/10.1016/j. ccell.2017.02.009)

Radulovich N, Leung L, Ibrahimov E, Navab R, Sakashita S, Zhu CQ, Kaufman E, Lockwood WW, Thu KL, Fedyshyn Y, et al. 2015 Coiledcoil domain containing 68 (CCDC68) demonstrates a tumorsuppressive role in pancreatic ductal adenocarcinoma. Oncogene $\mathbf{3 4}$ 4238-4247

Raffel S, Falcone M, Kneisel N, Hansson J, Wang W, Lutz C, Bullinger L, Poschet G, Nonnenmacher Y, Barnert A, et al. 20172017 BCAT1 restricts alphaKG levels in AML stem cells leading to IDHmut-like DNA hypermethylation. Nature 551 384-388. (https://doi. org/10.1038/nature24294)

Raychaudhuri P \& Park HJ 2011 FoxM1: a master regulator of tumor metastasis. Cancer Research 71 4329-4333. (https://doi. org/10.1158/0008-5472.CAN-11-0640)

Recouvreux MV \& Commisso C 2017 Macropinocytosis: a metabolic adaptation to nutrient stress in cancer. Frontiers in Endocrinology $\mathbf{8}$ 261. (https://doi.org/10.3389/fendo.2017.00261)

Riggs AD \& Xiong Z 2004 Methylation and epigenetic fidelity. PNAS 101 4-5. (https://doi.org/10.1073/pnas.0307781100)

Robertson KD 2001 DNA methylation, methyltransferases, and cancer. Oncogene 20 3139-3155. (https://doi.org/10.1038/sj.onc.1204341)

Rodriguez-Canales J, Hanson JC, Tangrea MA, Erickson HS, Albert PS, Wallis BS, Richardson AM, Pinto PA, Linehan WM, Gillespie JW, et al. 2007 Identification of a unique epigenetic submicroenvironment in prostate cancer. Journal of Pathology 211410 419. (https://doi.org/10.1002/path.2133)

Rose NR \& Klose RJ 2014 Understanding the relationship between DNA methylation and histone lysine methylation. Biochimica et Biophysica Acta 1839 1362-1372. (https://doi.org/10.1016/j. bbagrm.2014.02.007)

Rupaimoole R, Calin GA, Lopez-Berestein G \& Sood AK 2016 miRNA deregulation in cancer cells and the tumor microenvironment. Cancer Discovery 6 235-246. (https://doi.org/10.1158/2159-8290. CD-15-0893)

Saito S, Kawamura T, Higuchi M, Kobayashi T, Yoshita-Takahashi M, Yamazaki M, Abe M, Sakimura K, Kanda Y, Kawamura H, et al. 2015 RASAL3, a novel hematopoietic RasGAP protein, regulates the number and functions of NKT cells. European Journal of Immunology 45 1512-1523. (https://doi.org/10.1002/eji.201444977)

Sandsmark E, Andersen MK, Bofin AM, Bertilsson H, Drablos F, Bathen TF, Rye MB \& Tessem MB 2017 SFRP4 gene expression is increased in aggressive prostate cancer. Scientific Reports 714276

Scheffzek K \& Shivalingaiah G 2019 Ras-specific GTPase-activating proteins-structures, mechanisms, and interactions. Cold Spring Harbor
This work is licensed under a Creative Commons Attribution 4.0 International License. 
Perspectives in Medicine 9 a031500. (https://doi.org/10.1101/ cshperspect.a031500)

Schmechel D, Marangos PJ \& Brightman M 1978 Neurone-specific enolase is a molecular marker for peripheral and central neuroendocrine cells. Nature 276 834-836. (https://doi. org/10.1038/276834a0)

Schroder B 2016 The multifaceted roles of the invariant chain CD74-more than just a chaperone. Biochimica et Biophysica Acta 1863 1269-1281.

Sen DR, Kaminski J, Barnitz RA, Kurachi M, Gerdemann U, Yates KB, Tsao HW, Godec J, LaFleur MW, Brown FD, et al. 2016 The epigenetic landscape of T cell exhaustion. Science 354 1165-1169. (https://doi.org/10.1126/science.aae0491)

Simanshu DK, Nissley DV \& McCormick F 2017 RAS proteins and their regulators in human disease. Cell 170 17-33. (https://doi. org/10.1016/j.cell.2017.06.009)

Smith B, Agarwal P \& Bhowmick NA 2017 MicroRNA applications for prostate, ovarian and breast cancer in the era of precision medicine. Endocrine-Related Cancer 24 R157-R172. (https://doi.org/10.1530/ ERC-16-0525)

Smits M, van Rijn S, Hulleman E, Biesmans D, van Vuurden DG, Kool M, Haberler C, Aronica E, Vandertop WP, Noske DP, et al. 2012 EZH2-regulated DAB2IP is a medulloblastoma tumor suppressor and a positive marker for survival. Clinical Cancer Research 18 4048-4058. (https://doi.org/10.1158/1078-0432.CCR-12-0399)

Song Y, Fu LJ, Li HT \& Qiu XG 2019 Evaluation of MEDAG gene expression in papillary thyroid microcarcinoma: associations with histological features, regional lymph node metastasis and prognosis. Scientific Reports 95800.

Sproul D \& Meehan RR 2013 Genomic insights into cancer-associated aberrant CpG island hypermethylation. Briefings in Functional Genomics 12 174-190. (https://doi.org/10.1093/bfgp/els063)

Stefanska B, Cheishvili D, Suderman M, Arakelian A, Huang J, Hallett M, Han ZG, Al-Mahtab M, Akbar SM, Khan WA, et al. 2014 Genomewide study of hypomethylated and induced genes in patients with liver cancer unravels novel anticancer targets. Clinical Cancer Research 20 3118-3132. (https://doi.org/10.1158/1078-0432.CCR-130283)

Still ER \& Yuneva MO 2017 Hopefully devoted to Q: targeting glutamine addiction in cancer. British Journal of Cancer 116 1375-1381. (https:// doi.org/10.1038/bjc.2017.113)

Sun B, Hou YL, Hou WR, Zhang SN, Ding X \& Su XL 2012 cDNA cloning, overexpression, purification and pharmacologic evaluation for anticancer activity of ribosomal protein L23A gene (RPL23A) from the Giant Panda. International Journal of Molecular Sciences $\mathbf{1 3}$ 2133-2147.

Takayama KI, Suzuki T, Fujimura T, Takahashi S \& Inoue S 2018 COBLL1 modulates cell morphology and facilitates androgen receptor genomic binding in advanced prostate cancer. PNAS 115 4975-4980.

Takebayashi S, Tamura T, Matsuoka C \& Okano M 2007 Major and essential role for the DNA methylation mark in mouse embryogenesis and stable association of DNMT1 with newly replicated regions. Molecular and Cellular Biology 27 8243-8258. (https://doi.org/10.1128/MCB.00899-07)

Tan HL, Sood A, Rahimi HA, Wang W, Gupta N, Hicks J, Mosier S, Gocke CD, Epstein JI, Netto GJ, et al. $2014 \mathrm{Rb}$ loss is characteristic of prostatic small cell neuroendocrine carcinoma. Clinical Cancer Research 20 890-903. (https://doi.org/10.1158/1078-0432.CCR-13-1982)

Teo WW, Merino VF, Cho S, Korangath P, Liang X, Wu RC, Neumann NM, Ewald AJ \& Sukumar S 2016 HOXA5 determines cell fate transition and impedes tumor initiation and progression in breast cancer through regulation of E-cadherin and CD24. Oncogene 35 5539-5551.

Teufel A, Weinmann A, Galle PR \& Lohse AW 2005 In silico characterization of LZTS3, a potential tumor suppressor. Oncology Reports 14 547-551.
Tirosh I \& Barkai N 2008 Two strategies for gene regulation by promoter nucleosomes. Genome Research 18 1084-1091. (https://doi. org/10.1101/gr.076059.108)

Trimboli AJ, Cantemir-Stone CZ, Li F, Wallace JA, Merchant A, Creasap N, Thompson JC, Caserta E, Wang H, Chong JL, et al. 2009 Pten in stromal fibroblasts suppresses mammary epithelial tumours. Nature 461 1084-1091. (https://doi.org/10.1038/nature08486)

Tyan SW, Hsu CH, Peng KL, Chen CC, Kuo WH, Lee EY, Shew JY, Chang KJ, Juan LJ \& Lee WH 2012 Breast cancer cells induce stromal fibroblasts to secrete ADAMTS1 for cancer invasion through an epigenetic change. PLOS ONE 7 e35128. (https://doi.org/10.1371/ journal.pone.0035128)

Vaishnavi A, Capelletti M, Le AT, Kako S, Butaney M, Ercan D, Mahale S, Davies KD, Aisner DL, Pilling AB, et al. 2013 Oncogenic and drugsensitive NTRK1 rearrangements in lung cancer. Nature Medicine 19 1469-1472. (https://doi.org/10.1038/nm.3352)

Valencia T, Kim JY, Abu-Baker S, Moscat-Pardos J, Ahn CS, ReinaCampos M, Duran A, Castilla EA, Metallo CM, Diaz-Meco MT, et al. 2014 Metabolic reprogramming of stromal fibroblasts through p62mTORC1 signaling promotes inflammation and tumorigenesis. Cancer Cell 26 121-135. (https://doi.org/10.1016/j.ccr.2014.05.004)

Vizoso M, Puig M, Carmona FJ, Maqueda M, Velasquez A, Gomez A, Labernadie A, Lugo R, Gabasa M, Rigat-Brugarolas LG, et al. 2015 Aberrant DNA methylation in non-small cell lung cancer-associated fibroblasts. Carcinogenesis 36 1453-1463. (https://doi.org/10.1093/ carcin/bgv146)

Wang CA, Drasin D, Pham C, Jedlicka P, Zaberezhnyy V, Guney M, Li H, Nemenoff R, Costello JC, Tan AC, et al. 2014 Homeoprotein Six2 promotes breast cancer metastasis via transcriptional and epigenetic control of E-cadherin expression. Cancer Research 74 7357-7370.

Wang Z, Wang J, Su Y \& Zeng Z 2015 RASAL2 inhibited the proliferation and metastasis capability of nasopharyngeal carcinoma. International Journal of Clinical and Experimental Medicine 8 18765-18771.

Wang ZR, Wei JH, Zhou JC, Haddad A, Zhao LY, Kapur P, Wu KJ, Wang B, Yu YH, Liao B, et al. 2016 Validation of DAB2IP methylation and its relative significance in predicting outcome in renal cell carcinoma. Oncotarget 7 31508-31519. (https://doi. org/10.18632/oncotarget.8971)

Wang X, Sheng W, Wang Y, Li L, Li Y, Zhang S, Liu X, Chen S \& Zhen Y 2018 A macropinocytosis-intensifying albumin domain-based scFv antibody and its conjugate directed against K-Ras mutant pancreatic cancer. Molecular Pharmaceutics 15 2403-2412. (https://doi. org/10.1021/acs.molpharmaceut.8b00234)

Wiedenmann B, Franke WW, Kuhn C, Moll R \& Gould VE 1986 Synaptophysin: a marker protein for neuroendocrine cells and neoplasms. PNAS 83 3500-3504. (https://doi.org/10.1073/ pnas.83.10.3500)

Wu Y, Garmire LX \& Fan R 2012 Inter-cellular signaling network reveals a mechanistic transition in tumor microenvironment. Integrative Biology 4 1478-1486. (https://doi.org/10.1039/c2ib20044a)

Wu J, Gu Y, Xiao Y, Xia C, Li H, Kang Y, Sun J, Shao Z, Lin Z \& Zhao X 2018 Characterization of DNA methylation associated gene regulatory networks during stomach cancer progression. Frontiers in Genetics 9 711. (https://doi.org/10.3389/fgene.2018.00711)

Xiao M, Yang H, Xu W, Ma S, Lin H, Zhu H, Liu L, Liu Y, Yang C, Xu Y, et al. 2012 Inhibition of alpha-KG-dependent histone and DNA demethylases by fumarate and succinate that are accumulated in mutations of FH and SDH tumor suppressors. Genes and Development 26 1326-1338. (https://doi.org/10.1101/gad.191056.112)

Xiao Q, Zhou D, Rucki AA, Williams J, Zhou J, Mo G, Murphy A, Fujiwara K, Kleponis J, Salman B, et al. 2016 Cancer-associated fibroblasts in pancreatic cancer are reprogrammed by tumor-induced alterations in genomic DNA methylation. Cancer Research 76 5395-5404. (https://doi.org/10.1158/0008-5472.CAN-15-3264)

Xing D, Wang J, Ou S, Wang Y, Qiu B, Ding D, Guo F \& Gao Q 2014 Expression of neonatal Nav1.5 in human brain astrocytoma and its

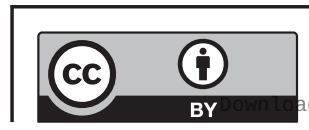

This work is licensed under a Creative Commons Attribution 4.0 International License. 
effect on proliferation, invasion and apoptosis of astrocytoma cells. Oncology Reports 31 2692-2700.

Xu X, Tan X, Tampe B, Nyamsuren G, Liu X, Maier LS, Sossalla S, Kalluri R, Zeisberg M, Hasenfuss G, et al. 2015 Epigenetic balance of aberrant Rasal1 promoter methylation and hydroxymethylation regulates cardiac fibrosis. Cardiovascular Research 105 279-291.

Yadav KK, Shameer K, Readhead B, Yadav SS, Li L, Kasarskis A, Tewari AK \& Dudley JT 2016 Systems medicine approaches to improving understanding, treatment, and clinical management of neuroendocrine prostate cancer. Current Pharmaceutical Design 22 5234-5248. (https://doi.org/10.2174/1381612822666160513145924)

Yan L, Zhou J, Gao Y, Ghazal S, Lu L, Bellone S, Yang Y, Liu N, Zhao X, Santin AD, et al. 2015 Regulation of tumor cell migration and invasion by the H19/let-7 axis is antagonized by metformin-induced DNA methylation. Oncogene 34 3076-3084. (https://doi.org/10.1038/ onc.2014.236)

Yan M, Li X, Tong D, Han C, Zhao R, He Y \& Jin X 2016 miR-136 suppresses tumor invasion and metastasis by targeting RASAL2 in triple-negative breast cancer. Oncology Reports 36 65-71. (https://doi. org/10.3892/or.2016.4767)

Yang X, Duan B \& Zhou X 2017 Long non-coding RNA FOXD2-AS1 functions as a tumor promoter in colorectal cancer by regulating EMT and Notch signaling pathway. European Review for Medical and Pharmacological Sciences 21 3586-3591.

Yano M, Toyooka S, Tsukuda K, Dote H, Ouchida M, Hanabata T, Aoe M, Date H, Gazdar AF \& Shimizu N 2005 Aberrant promoter methylation of human DAB2 interactive protein (hDAB2IP) gene in lung cancers. International Journal of Cancer 113 59-66. (https://doi. org/10.1002/ijc.20531)

Yu J, Walter K, Omura N, Hong SM, Young A, Li A, Vincent A \& Goggins M 2012 Unlike pancreatic cancer cells pancreatic cancer associated fibroblasts display minimal gene induction after 5-aza-2'-deoxycytidine. PLoS ONE 7 e43456. (https://doi.org/10.1371/ journal.pone.0043456)

Yuan H, Kajiyama H, Ito S, Yoshikawa N, Hyodo T, Asano E, Hasegawa H, Maeda M, Shibata K, Hamaguchi M, et al. 2013 ALX1 induces snail expression to promote epithelial-to-mesenchymal transition and invasion of ovarian cancer cells. Cancer Research $\mathbf{7 3}$ 1581-1590.

Zhai LL, Xie Q, Zhou CH, Huang DW, Tang ZG \& Ju TF 2017 Overexpressed HSPA2 correlates with tumor angiogenesis and unfavorable prognosis in pancreatic carcinoma. Pancreatology 17 457-463.

Zhang B, Pan X, Cobb GP \& Anderson TA 2007 MicroRNAs as oncogenes and tumor suppressors. Developmental Biology 302 1-12. (https://doi.org/10.1016/j.ydbio.2006.08.028)

Zhang H, Wang Y, Liu Z, Yao B, Dou C, Xu M, Li Q, Jia Y, Wu S, Tu K, et al. 2016 Lymphocyte-specific protein 1 inhibits the growth of hepatocellular carcinoma by suppressing ERK1/2 phosphorylation. FEBS Open Bio 6 1227-1237.

Zhang JY, Zhang PP, Zhou WP, Yu JY, Yao ZH, Chu JF, Yao SN, Wang C, Lone W, Xia QX, et al. 2019 L-type cav 1.2 calcium channelalpha-1C regulates response to rituximab in diffuse large B-cell lymphoma. Clinical Cancer Research 25 4168-4178.

Zong M, Meng M \& Li L 2011 Low expression of TBX4 predicts poor prognosis in patients with stage II pancreatic ductal adenocarcinoma. International Journal of Molecular Sciences 12 4953-4963.

Zong Y, Huang J, Sankarasharma D, Morikawa T, Fukayama M, Epstein JI, Chada KK \& Witte ON 2012 Stromal epigenetic dysregulation is sufficient to initiate mouse prostate cancer via paracrine Wnt signaling. PNAS 109 E3395-E3404. (https://doi. org/10.1073/pnas.1217982109)

Zwartkruis FJ \& Burgering BM 2013 Ras and macropinocytosis: trick and treat. Cell Research 23 982-983. (https://doi.org/10.1038/cr.2013.79)

Received in final form 9 October 2019

Accepted 17 October 2019

Accepted Preprint published online 18 October 2019 (c) 2019 The authors Published by Bioscientifica Ltd. Printed in Great Britain
This work is licensed under a Creative Commons Attribution 4.0 International License. 